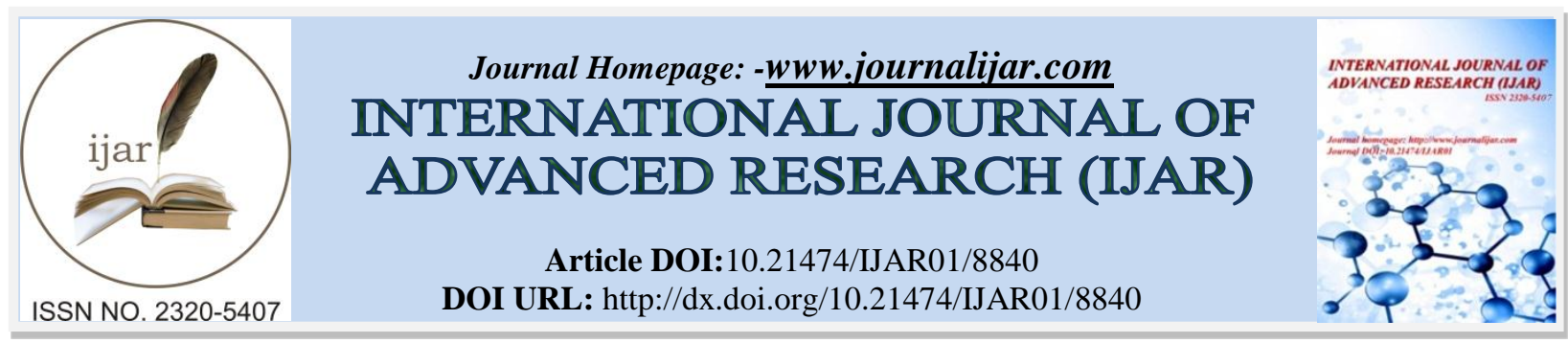

RESEARCH ARTICLE

\title{
USE OF ICT-BASED INFORMATION SYSTEMS ON MAIZE (ZEA MAYS) MARKETING AMONG SMALLHOLDER FARMERS IN KENYA.
}

Wanjala Nafula Rose and Okumu Lusike Mary

Masinde Muliro University of Science and Technology, Kenya.

\section{Manuscript Info}

Manuscript History

Received: 07 February 2019

Final Accepted: 09 March 2019

Published: April 2019

Key words: -

Zea Mays, Kenya Agricultural

Commodity Exchange (KACE),

Management Information Systems

(MIS), Information and Communication

Technology (ICT), Market Information.

\begin{abstract}
This study evaluated the impact of Information Communication Technology (ICT)-based marketing, drawing lessons from an ICTbased MIS projects in western Kenya. Data was collected from a sample of 192 farmers randomly selected using multi-stage random sampling procedure. Typically, men within the middle age range were determined to be active participants in farming and the major consumers of farm produce. In regard to technology adoption, both genders demonstrated a balanced capability. A Chi square test using Statistical Package for the Social Sciences (SPSS) version 21 was used to test the relationship between the various ICT tools and maize marketing. Results show that there was a high variation in ICT tools used by farmers. Mobile telephony and radio were the commonly used (36.5\%) ICT by the farmers. Internet was the least used at $4.7 \%$. Majority $(95.5 \%)$ of the respondents reported positive contribution by ICT in farming produce and incomes while $4.2 \%$ reported no change. There was a high variation in the effect of ICT services on household maize marketing. Of the respondents, $64.4 \%$ identified inadequate funds as a major constrain in application of ICT tools. As such, it is quite apparent that farmers have put in more effort to utilize technology, only that they still face few problems that need to be handled to ensure full integration of technology into farming.
\end{abstract}

Copy Right, IJAR, 2019. All rights reserved.

\section{Introduction:-}

The e-agriculture concept combines the advances in agricultural informatics, agricultural development and entrepreneurship to provide better agricultural services, enhanced technology dissemination and information delivery. This is achieved through the various advances made in ICT. Farmers profit from information related to best practices and technologies for crop production, weather, postharvest handling, processing, marketing, storage, and handling. The quest for rural development cannot succeed without increasing the role of the overwhelming majority of small holder farmers. However, the large numbers of smallholder farmers face challenges in information provision. Increased use of ICT would increase productivity and competitiveness for the development of smallholder agriculture through fostering greater linkage of smallholder farmers to market opportunities and to the rest of national and global economy through a multiplier effect at the local communities. In this regard, creating an entrepreneurship culture in the rural economies is vital to help smallholder farmers thrive. 
Several public-private sector interventions have emerged. Their target is on the provision of ICT-based market information services to farmers. A widespread application of ICT tools in agriculture, such as the internet, mobile phones and interactive video, majority of which target smallholder farmers. The proliferation of ICT-based Management Information System (MIS) was greatest in Africa where rapid penetration of cell phones had created interest in the opportunities that exist in applying ICTs in agriculture (Mukhebi, 2007). In spite of the potential of ICT to transform agricultural production among the smallholder farmers, little is still known about the actual benefits to smallholder farmers and the impact of ICT-based MIS in transforming smallholder agriculture.

Kenya Agricultural Commodity Exchange (KACE) was launched in 1997 to facilitate linkage between sellers and buyers of agricultural commodities, provide relevant and timely marketing information and intelligence, facilitate transparent and competitive market price discovery mechanism, harness and apply ICT for rural value addition and empowerment. KACE allows farmers with mobile phones to check latest commodity prices, potential buyers and prices of commodities. As such, this is one of the ICT applications that have so far been executed to promote farming. However, more effort is still need to promote an ICT driven farming. Accordingly, the study will focus on achieving the following objectives.

\section{Objectives}

\section{Broad objective}

The general objective of the study is to evaluate the use of Information Communication Technology (ICT)-based marketing, drawing lessons from an ICT-based MIS projects in western Kenya

\section{Specific Objectives}

1. To determine the actual benefits of ICT-based information provision to smallholder farmers

2. To determine the impact of ICT-based MIS in transforming smallholder agriculture.

3. To ascertain the current application of ICT in farming

\section{Methodology: -}

\section{Description of the study area}

The study was performed in two counties of western Kenya, Bungoma and Kakamega, that had been involvement in the Kenya Agricultural Commodity Exchange Management Information Systems (KACEMIS) projects over time The two counties are in the moist mid-altitude agro-ecological zone. The zone is sub-divided into agro-ecological zones (AEZ) Lowe Midlands (LM) ${ }_{1}$ to Lower Midland (LM) ${ }_{4}$ zones based on altitude, which ranges between 1,1001,500 meters above sea level. Mean annual temperature is $12-24^{\circ} \mathrm{C}$, while mean minimum temperature is more than $14{ }^{\circ} \mathrm{C}$. There are contrasts of rainfall, mainly due to local air circulation. Annual rainfall averages $700-1800 \mathrm{~mm}$ and is bi-modal. The rainfall amount and pattern are modified by altitude; higher elevation areas receive relatively more rainfall. First rainy season in a year starts in February/March and the second in August/September. Most farming activities follow the rainfall pattern. Soils are varied, but are mostly clay-loam and sandy-loam or some soils have literate horizons. Farmers in the area are generally subsistence producers with incidental surplus sold in markets. Middlemen are the main buyers of farm produce. This is attributed to the absence of market organizations, limited knowledge by farmers about marketing and high cost of market transactions.

\section{Data Collection}

Primary and secondary data sources were utilized. The primary data were generated through interview of household heads. Key informants were contacted through a Participatory Rural Appraisal (PRA) approach. The secondary data was obtained from relevant literatures such as text books, peer-reviewed journals, conference proceedings, credible reports, and official documents from KACE and other government institutions. Data from key informants about constraints and opportunities was collected through focused group, discussions and interview schedules. Data collected from different sources were codified in a single database.

\section{Sampling procedures and Sample Size}

Multi-stage sampling technique was applied to select the study sites that represent diverse ecological and socioeconomic environment and varying maize production, as well as marketing systems in the two counties. The zone was first stratified into the administrative divisions to allow capturing the diversity in economic and political leadership that may influence the nature of marketing projects and investment in an area. Stratified sampling was 
done to identify farmers randomly from strata that initially benefited from KACEMIS services and subsequent neighbor farmers that were non-beneficiaries.

For the multi-stage sampling procedure, the first step was to select two locations randomly from the divisions identified earlier. Secondly, a list of all sub-locations in each of the selected divisions was obtained from respective administrative staff. The third process involved random selection of two villages from each sub-location to form a sampling frame of all farmers in the villages. Finally, the sample units were selected using a systematic random sampling procedure to form a sample size of 192 households.

\section{Data Analysis.}

Two different Pre-tested questionnaires were administered to the heads of households of both KACEMIS members and nonmembers respectively. They consisted of items on farmer background, ICT tools \& services, (mobile phone, radio, television and internet), factors influencing choice and application of ICT. Correlational research design was used to generate the data. The data was analyzed using descriptive statistics, namely; frequencies percentages, and histograms).

\section{Results and Discussion: -}

\section{ICT tools used by farmers to access agriculture marketing information}

Results in Table 1 shows that all respondents had used a mobile phone as a marketing tool. Those who had used only mobile phones were $9.4 \%$ while $36.5 \%$ used both mobile phone and radio, and $22.4 \%$ used mobile phone, radio and rural based market information points blackboards(MIPs). Of the respondents, $17.7 \%$ used a mobile phone, radio and posters, 5.2\% used mobile phones, internet and radio, $4.7 \%$ used mobile phones and internet while $4.2 \%$ used mobile phones, radio, TV and posters. Radio and the mobile phone were the most commonly used ICT tools. Based on these findings, it is quite clear that individuals have embraced the use of technology in farming positively. This case shows that individuals are ready to embrace the industrial age by accommodating new advances into their usage, for instance, from posters, to radios, TVs, phones, and now the internet. Accordingly, the results correlate those established by Munyua (2007), inferring a positive motivation that more advances will be accommodated as required.

Table 1:-ICT tools used by farmers in agricultural marketing

\begin{tabular}{|l|l|l|}
\hline ICT Tool & Frequency & Percentage \\
\hline Mobile phone & 18 & 9.4 \\
\hline Mobile phone and radio & 70 & 36.5 \\
\hline Mobile phone, radio and rural based market information points (MIPs) & & \\
& 43 & 22.4 \\
\hline Mobile phone, radio and posters & 34 & 17.7 \\
\hline Mobile phone, internet and radio & 10 & 5.2 \\
\hline Mobile phone and internet & 9 & 4.7 \\
\hline Mobile phone, radio, TV and posters & 8 & 4.2 \\
\hline Total & $\mathbf{1 9 2}$ & $\mathbf{1 0 0 . 0}$ \\
\hline
\end{tabular}

The Mobile Phone SMS referring to SMS SOKONI AND SMS SOKO LEO products were used to provide buying or selling information on maize by sending messages to registered numbers. Both services were provided in languages best understood by the communities such as Swahili and English. Soko Hewani provides timely market information and facilitated market linkages for farmers and SMEs through an interactive radio program. KACE also had Internet based database system (Websites and Email), where agricultural marketing information was disseminated. As shown in table 1, most of the farmers use ICT tools for accessing market-related information and are aware of the existence of ICT services that provided information on farming and marketing of agricultural produce.

\section{Influence of gender and education level on use of ICT}

As shown in table 2, the rate at which women are using technology is higher than that of men. Percentagewise, men who use technology for this purpose had $26.0 \%$ against $29.9 \%$ of those who do not use technology. This clearly shows that the female gender is more technology oriented than their male counterparts. Women who use technology for the same purpose scored $24.0 \%$ against 20.1 of those who are yet to embrace MIS. In this regard, the results of 
Rakow (2016)'s study that gender no longer influence the use of ICT in agriculture are justified. Rather, there is divergence in arguments, given that women and men who adopt ICT are almost at equilibrium.

Table 2: -Use of MIS based on gender and education level of the heads of the households

\begin{tabular}{|l|l|l|}
\hline Characteristics of household head & \% of farmers using MIS & \% of farmers not using MIS \\
\hline Gender of household heads & & \\
\hline Male & 26.0 & 29.9 \\
\hline Female & 24.0 & 20.1 \\
\hline Total & 50.0 & 50.0 \\
\hline Education Level of household head & & \\
\hline Primary (0-8 years of education) & 26.9 & 2.5 \\
\hline Secondary (>8 to <12 years of education) & 13.7 & 28.0 \\
\hline Tertiary (> 12 years of education) & 12.1 & 16.8 \\
\hline Total & 52.7 & 47.3 \\
\hline
\end{tabular}

Results in Figure 1 show that majority of the respondents were in the age bracket of 20-40 and above 50 years. Apparently, those in the age range between 20-40 years are millennials. One of their characteristics is the eagerness to embrace technology at all cost, given that most of them were born at the dawn of technological inventions. Individuals between 40-50 years were mostly engaged in activities outside farming, thus, it could not be established whether or not, they utilized technology for other purposes. Those above 50 years participated due to the influence they received from their kids, who mostly comprise millennials.

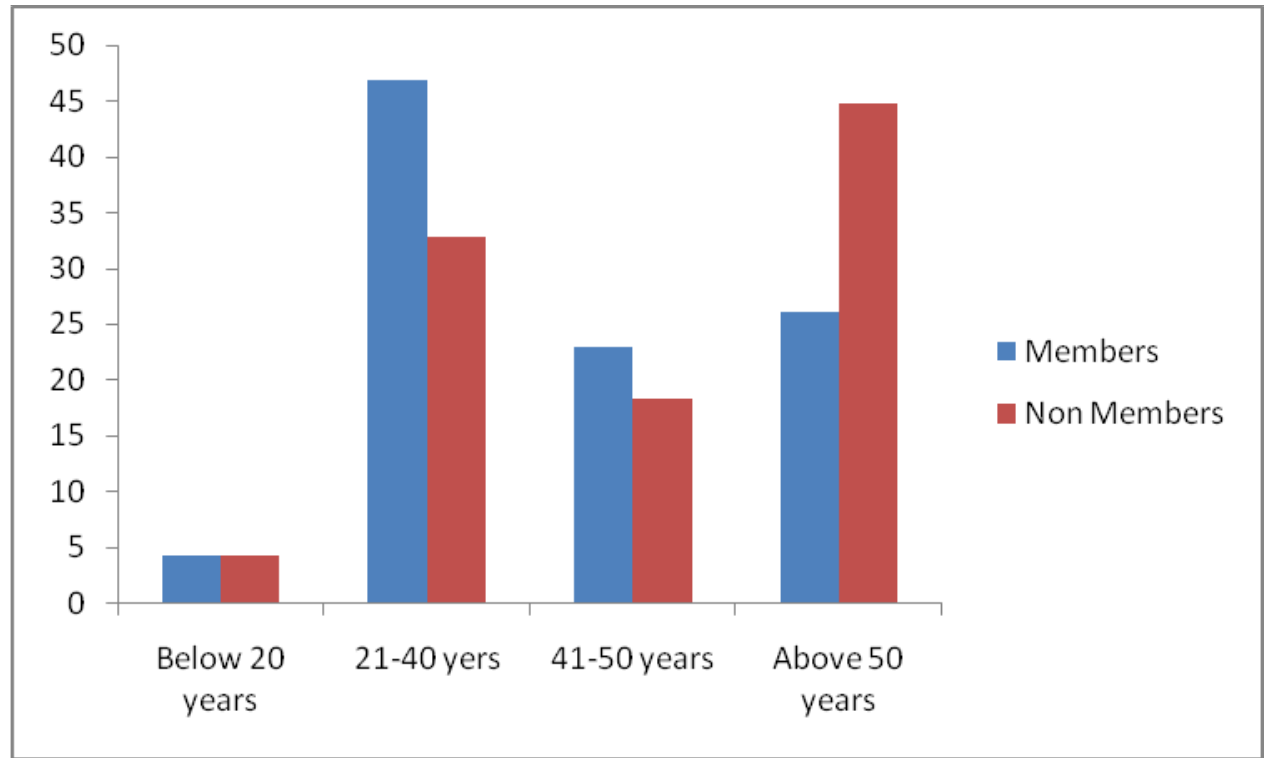

Figure 1: -Respondents' age distribution as members and nonmembers of MISs

\section{Impact of MIS membership on the household marketing of maize}

From the descriptive statistics, $91.7 \%$ of members reported an increase in household marketing of maize while $8.3 \%$ said that there was no change at all. None of the respondents recorded a decrease in the number of sales. This is an indication that most of the respondents were benefiting from being members of KACE MIS (Table 3).

\begin{tabular}{|l|l|l|l|l|}
\hline Chi-square value & df & P-value & Decision & Remark \\
\hline & 1 & & Significant/not significant & $\begin{array}{l}\text { Accept/reject } \\
\text { null/alternative } \\
\text { hypothesis }\end{array}$ \\
\hline
\end{tabular}


Table 3:-Impact of MIS membership on the household marketing of maize

\begin{tabular}{|l|l|l|}
\hline Change & Frequency & Percentage \\
\hline Increased what? & 176 & 91.7 \\
\hline No change at all & 16 & 8.3 \\
\hline Total & $\mathbf{1 9 2}$ & $\mathbf{1 0 0 . 0}$ \\
\hline
\end{tabular}

\section{Benefits of being members of KACE MIS}

There was a high variation in the benefits derived by farmers from being members of KACE MIS. The benefits included extension services (36.5\%), commodity market information (27.6\%), micro-credit and revolving fund (22.9\%), seeds and fertilizers information (4.7\%), experience sharing (4.2\%), as well as maize collection and transportation (4.2\%). KACE MIS members greatly were able to utilize KACE MIS for a competitive advantage as they had sufficient information about the market demand and could increase their productivity through utilizing available information on seeds and fertilizers, as well as the gained experienced.

Table 4: -Benefits accruing from using MIS to members of farmer groups

\begin{tabular}{|l|l|l|}
\hline Benefit to members of farmer group & $\begin{array}{l}\text { Percentage of } \\
\text { farmers } \\
\text { benefiting }\end{array}$ & $\begin{array}{l}\text { Ranking of the } \\
\text { benefit } \\
\text { members }\end{array}$ \\
\hline Extension services & 36.5 & 1 \\
\hline Experience sharing & 4.2 & 5 \\
\hline Maize collection and transportation & 4.2 & 5 \\
\hline Commodity Market information & 27.6 & 2 \\
\hline Micro-credit, revolving fund & 22.9 & 3 \\
\hline Seeds and fertilizers information & 4.7 & 4 \\
\hline Total & $\mathbf{1 0 0 . 0}$ & \\
\hline
\end{tabular}

Ranking where 1 very important, 5 least important

Choice and application of ICT tools in access to agriculture market information and commodity markets by smallholder farmers.

Majority (62.5\%) of respondents had used ICT tools for between two and five years. Most of the farmers had become active applicants of ICT tools within the first five years. There was a high variation in the distance from farmer's farms to the nearest MIS group. Of all the respondents, $41.1 \%$ were within a radius of less than a kilometer, $27.1 \%$ represented those whose farms were 1-2 kilometers and 11-20 kilometers while $4.7 \%$ were more than $20 \mathrm{~km}$ away from the nearest MIS. This indicated that majority of respondents (95.3) were less than 20 kilometers from the nearest MIS. Proximity to the MIS group is an important factor as it enables farmers to easily access extension information from the MIS. It also enables MIS members to regularly meet, plan and share their personal experiences regarding their farming activities. Majority (77.1\%) of MIS members shared current market information with other farmers while only few (22.9\%) did not share current market information with other farmers. This implies that some farmers who may not be members of any MIS group could still access marketing information from MIS group. This spill-over effect plays a role as it helps improve access to current market information. Majority (71.9\%) of respondents were members of a stakeholders' forum while $28.1 \%$ belonged to MIS groups that were not. Stakeholders' forum. Collaboration enhanced the process of market information sharing.

The major constraint faced by MIS groups was inadequate funds (64.6\%) followed by unavailability of tools (22.4\%). Others were inadequate knowledge (4.7\%), lack of group cohesion $(4.2 \%)$ and inaccessibility to market information system. Other problems related to rural infrastructure (poor network connectivity, poor rural roads and lack of transport), while others relate to adverse trader behavior (inaccurate scales), or (adverse farmer behavior/poor quality crops for sale). Lack of credit is an important factor for traders, given that they have to purchase before they realize an income from sales (Tollens, 2006). Some of these problems are susceptible to improvement through the use of MIS services (especially those related to bringing buyers and sellers together, and price knowledge), while others relate to broader problems in the transaction costs of markets that cannot easily be tackled by improvements in MIS alone (Okello \& Adera-Ofwona, 2009). There is therefore need for government policy intervention. 
Table 5: -Constraints faced by MIS groups

\begin{tabular}{|l|l|}
\hline Constraint & Percentage \\
\hline Inadequate funds & 64.6 \\
\hline Unavailability of farm inputs & 22.4 \\
\hline Inadequate knowledge in crop/ livestock production & 4.7 \\
\hline Lack of group cohesion & 4.2 \\
\hline Inaccessibility to market information & 4.2 \\
\hline Total & $\mathbf{1 0 0 . 0}$ \\
\hline
\end{tabular}

\section{Conclusions: -}

The diffusion of MIS in western Kenya has been successful in many ways although there are a number of challenges that needs to be addressed before the full benefits can be achieved. Access to ICTs as source of information seems to have the potential to provide equity in accessing information among members of the farming community in western Kenya. The focus of the study was to evaluate the use of ICT-based marketing, drawing lessons from an ICT-based MIS projects in western Kenya. Apparently, gender differences did not influence the adoption of ICT in farming. Both men and women embraced the use of technology by registering with KACE MIS. Accordingly, they stood a competitive advantage through increased productivity, gaining experience, acquiring marketing information, as well as insights about seeds and fertilizers. However, there is still need to fund KACE MIS projects in this region to enhance its use among farmers who are yet to make their decision in regard to its adoption.

\section{References: -}

1. Mukhebi, A. (2007). Malawi Agricultural Commodity Exchange: Franchised Market Information Points. A Consultancy Report to Initiative for Development and Equity in African Agriculture (IDEAA), Malawi by Kenya Agricultural Commodity Exchange Limited (KACE). Nairobi: Government Press

2. Munyua, H. (2007). ICTs and small-scale agriculture in Africa: a scoping study. Draft Report 1 Submitted to International Development Research Centre. Nairobi: University of Nairobi

3. Okello, JJ. \& Adera-Ofwona, E. (2009). Awareness and use of mobile phones by smallholder farmers in Kenya. E-Agriculture and E-Government for Global Policy Development: Implications and Future Directions. 2009. Hershey, Pennsylvania: IGI Publishers.

4. Rakow, L. (2016). Rethinking gender research in communication. Journal of Communication 36:11-36.

5. Tollens, E. F., (2006). Market Information Systems in sub-Sahara Africa: Challenges and Opportunities. Poster paper presented at the International Association of Agricultural Economists Conference. Gold Coast, Australia 